\title{
Changing Habits of Rural \& Urban People of Nutritional Dietary
}

Prof.S.B.Shivkumar

\author{
Associate Professor, Dept. of Sociology \\ Adichunchanagiri First Grade College \\ Channarayapatna, Hassan-Dist \\ shivakumar.sb1957@gmail.com
}

\begin{abstract}
The Study examined the relationship between the nutritional habit of rural and urban people of kolar district, Karnataka state. The nutritional life style examined includes the difference in proteins, calories, vitamins and minerals consumption by the rural and urban people of kolar district, Karnataka state. It also examined their attitude towards the consumption of natural and refined food products. Descriptive research design was adopted for the study. The population consisted of all individual age 16 years and above living in both rural and urban areas of kolar district of Karnataka state at the time of the study.
\end{abstract}

\section{INTRODUCTION}

The major cause of mortality in developed and developing countries of the world are diseases in which nutritional habit plays an important role. The choices of what people eat are determined by various factors such as religions, customs and socio-economic differences. The principal determinant is the environment in which an individual find himself or herself. Changing these factors in the direction of nutritional habit patterns could postpone the age of onset of permanent mobility, disability, disease occurrences and death and could have a major effect on quality of life (Bush et al., 1990; Verbrugge and Jette, 1994; Haveman et al., 2002; Mitrou et al., 2007; Waijerset al., 2006). As pointed out above, the nutritional habit of an individual is influenced by a variety of external and internal factors based on the complex interactions between the individual and his environment.

Sharma et al. (1996) and Mennen et al. (2000) reported that urban habit in Africa is characterized by changes in dietary habits involving an increase in consumption of refined sugars and saturated fat and a reduction in fibre intake. Majority depends on imported and refined food nutrients with little nutritional values which may have adverse effects on their well being. Moreover, there is reduction in physical activity with urban habits.

Rural population depends on available natural foods like green vegetables, fresh fruits and diary products in their immediate environment. Although, significant amount of refined food could also be noticeable in the rural areas such as bread, soft drinks and other refined or processed food products.

Nutrition is the entire process in which our bodies absorb and make use of foods; nutrients are those substances in foods that sustain our bodies. Nutrients serve three basic functions;

1) Building and repairing the body tissues,

2) Regulating body processes and

3) Supplying energy.

This study therefore group the nutrients we consume around the three basic functions stated above to include; (1) proteins, (2) vitamins and minerals and (3) carbohydrates, fats and oil.

Food choice is an important determinant of people's quality of life. Poor or unbalanced diets as in the case of excessive eating and under nutrition are risk factors for several chronic diseases. Poor food intake reduces the level of nutrients in the body thereby exposing the patients to nutritional health related problems. For example, a diet characterized by a high proportion of high-fat diary food, fatty containing sugars and by a low proportion of vegetables, fruits, cereals and legumes poses an increase risk of nutritional deficiency diseases. The choice of good nutrition is not only important in 
preventing health problems and promoting active living, but it is a critical part of managing diseases among those who are infected or sick (Haveman et al., 2003) .

The study examined the relationship between the nutritional habit of rural and urban people of Kolar district. It examined the difference in the consumption of proteins, carbohydrates and fats as well as vitamins and minerals salts. The study also examined the differences in the consumption of natural and refined food products among the people of Kolar district.

\section{MATerials AND MethodS}

This research was conducted in Malur, Kolar District, Karnataka State in between July 2015 and June 2016.

\section{Hypothesis}

There is no significant difference in the nutritional habit of rural and urban people of Kolar District, Karnataka State.

\section{Sub-Hypothesis}

Rural and urban peoples of Kolar District, Karnataka State are not significantly different in their protein consumption.

Rural and urban people of Kolar District, Karnataka State are not significantly different in their calories consumption.

Rural and urban people of Kolar District, Karnataka State are not significantly different in their vitamins and minerals salts consumption.

Rural and Urban people of Kolar District, Karnataka State are not significantly different in their consumption of natural food products.

Descriptive research design was adopted for this study. The population consists of all individuals from age 16 years and above living in Kolar District, Karnataka State as at the time of the study. A structured questionnaire, developed and pilot tested with a reliability analysis scale of $0.92 \mathrm{r}$ was used for the study. A total of 1350 respondents (rural 450 respondents, urban 900 respondents) were selected using a combination of stratified and cluster random sampling techniques. The researcher with the help of three research assistants who are fluent in the various local languages in the state (Kannada, Telugu, Tamil, Urdu etc) were actively involved in the administration of questionnaire, samples were drawn from the six rural area (Vokkaleri, Lakkuru, Tekal, Masthi) and six urban areas, (Malur City, Kolar, Srinivaspur, KGF, Mulbagal and Bangarpet,) carefully selected using random sampling techniques across the three senatorial districts of Kaduna state, Nigeria. Seventy five respondents were randomly selected from each of the rural areas, which 150 respondents were randomly selected from each of the urban areas.

The data that emanated from the study were statistically analyzed using student t-test using Statistical Package for Social Science.

\section{RESUlTS}

The result presented in Table 1 and 2 were strictly based on research questions. A careful examination of Table 1 shows that the calculated t-value of 1.70 is less than the critical value of 1.96 at 0.05 alpha level of significance. Therefore, the null hypothesis that says rural and urban people of Kolar District, Karnataka Stateare not significantly difference in the nutritional habit is accepted.

Table1. Means, standard deviation, standard error and t-value of difference between the nutritional habit of rural and urban respondents in Kolar district of Karnataka state.

\begin{tabular}{|c|c|c|c|c|c|c|c|c|}
\hline $\begin{array}{c}\text { Type of } \\
\text { dwelling }\end{array}$ & $\begin{array}{c}\text { No. of } \\
\text { Cases }\end{array}$ & Means & SD & SE & Df & $\begin{array}{c}\text { Cal.t- } \\
\text { value }\end{array}$ & $\begin{array}{c}\text { Ctitical } \\
\text { value }\end{array}$ & Remark \\
\hline Rural & 450 & 16.2311 & 4.323 & 0.204 & 1348 & 1.709 & 1.96 & Not sign \\
\hline Urban & 900 & 15.8011 & 4.396 & 0.147 & & & & \\
\hline Total & 1350 & & & & & & & \\
\hline
\end{tabular}


Table2. Means, standard deviation, standard error and t-value of differences in the consumption of protein, calories, vitamins, natural and refined food products by the rural and urban respondents of Kolar district, Karnataka State.

\begin{tabular}{|c|c|c|c|c|c|c|c|c|c|}
\hline Nutrition & $\begin{array}{c}\text { Type of } \\
\text { dwelling }\end{array}$ & $\begin{array}{l}\text { No. of } \\
\text { Cases }\end{array}$ & Means & SD & SE & Df & $\begin{array}{l}\text { Cal.t- } \\
\text { value }\end{array}$ & $\begin{array}{c}\text { Ctitical } \\
\text { value }\end{array}$ & Remark \\
\hline \multirow[t]{3}{*}{ Proteions } & Rural & 450 & 15.9094 & 4.303 & 0.134 & & -0.54 & 1.96 & Not Sign \\
\hline & Urban & 900 & 16.0209 & 4.607 & 0.261 & 1348 & & & \\
\hline & Total & 1350 & & & & & & & \\
\hline \multirow{3}{*}{$\begin{array}{c}\text { Calories } \\
\text { Carbohydrates, } \\
\text { Ois \& fats }\end{array}$} & Rural & 450 & 8.6002 & 2.691 & 0.153 & 1348 & 3.43 & 1.96 & Sign \\
\hline & Urban & 900 & 8.0032 & 2.707 & 0.084 & & & & \\
\hline & Total & 1350 & & & & & & & \\
\hline \multirow{3}{*}{$\begin{array}{c}\text { Vitamins \& } \\
\text { Minerals }\end{array}$} & Rural & 450 & 9.5971 & 4.134 & 0.128 & 1348 & -0.84 & 1.96 & Not Sign \\
\hline & Urban & 900 & 9.7276 & 4.521 & 0.266 & & & & \\
\hline & Total & 1350 & & & & & & & \\
\hline \multirow{3}{*}{$\begin{array}{l}\text { Consumption of } \\
\text { Refined Food \& } \\
\text { Products }\end{array}$} & Rural & 450 & 4.7700 & 4.598 & 0.183 & 1348 & 5.78 & 1.96 & Sign \\
\hline & Urban & 900 & 8.6222 & 5.655 & 0.267 & & & & \\
\hline & Total & 1350 & & & & & & & \\
\hline
\end{tabular}

$D f=N-2=1350-2=1348$, Critical value $=1.96, p<0.05$

This means that there is no significant difference in the nutritional habit of rural and urban people of the Kolar district, Karnataka State.

Table 2 shows that the calculated t-value for proteins $(-0.54)$ and vitamins and mineral salts $(-0.84)$ of the respondents were less than the critical/table value of 1.96 with a degree of freedom 1348 at 0.05 alpha level of significance. Therefore, the null hypothesis that says there are no significant difference in the proteins, vitamins and mineral salts consumption of rural and urban respondents of Kaduna state were upheld. This means that significant differences does not exist in the protein, vitamins and mineral salts consumption by rural and urban respondents of Kaduna state, Nigeria.

Table 2 also reveals that the calculated t-value for calories (3.43), natural foods (4.41) and refined or processed foods (5.78) were greater than the critical value of 1.96 with a degree of freedom 1348 at 0.05 alpha level of significance. Therefore, the null hypothesis that says rural and urban people of Kolar District, Karnataka State are not significantly different in their consumption of calories, natural and refined food products were rejected. This implies that significant difference exist between rural and urban respondents in their consumption of calories, natural and refined food products.

\section{DISCUSSION}

The finding that there is no significant difference in the nutritional habit of rural and urban of people of Kolar District, Karnataka State as presented in Table 1 is supported by the findings of such research reported that evidence shows the prevalent of poor nutritional basis in the rural areas resulting in food deficiency diseases like rickets, kwashiorkor, marasmus, scurvy, anaemia, osteoporosis and early mortality especially among the under-five and other vulnerable groups. Sharma et al. (1996) and Mennen et al. (2000) submitted that urban habit in developing countries is characterized by poor dietary habit involving an increase in consumption of refined sugars, saturated fats, imported and refined food nutrients with little nutritional values which may have adverse effects on their quality of life. The contradictory in the reports of the authors cited above, lay credence to the finding of this study that there is no significant difference in the nutritional habit of rural and urban people of Kolar district.

It was also found that rural and urban people of Kolar district.are not significantly different in their proteins, vitamins and mineral salts consumption. On proteins consumption, the respondents in both rural and urban areas of Kolar District, Karnataka State concord that they depends on plant and animal sources of protein for their daily protein which are readily available in their communities. Examples of protein foods listed by the respondents are soya beans, meat, poultry products, beans, fish (fresh and dry) etc., the average means of 15.9094 (rural) and 16.0209 (urban) which are closely related as presented in Table 2 is a pointer to this direction. On vitamins and mineral salts, while the rural people submitted that they can easily get their daily vitamins requirement from fruits and green vegetables from the neighborhood farms, the urban respondents believed that fresh fruits and green vegetables are abound in the market at affordable prices. The average means of 9.7276 (urban) and 9.5971(rural) which are closely related lay by credence to the finding that rural and urban respondents of Kolar district are not significantly different in their vitamins and mineral salts consumption. 


\section{CONCLUSION AND RECOMMENDATION}

Rural and urban people of Kolar district are not significantly different in their nutritional habit. Rural and urban people of Kaduna state are not significantly different in their consumption of proteins, vitamins and minerals salts nutrients. Rural and urban people of Kaduna state are significantly different in their consumption of calories, natural and refined food products.

Based on the finding of the study, the following recommendations are made: Health educate the people on the choice of food nutrients like protein, carbohydrate, vitamins, mineral, fats and oils in the current proportion would go a long way to influence or determine the nutritional habits of an individual. Appropriate health education interventions with prompt monitoring and surveillance activities by health practitioners, teachers, parents or guardians and other categories of health workers be put in place to check cases of early mortality among under and five other vulnerable groups occasioned by poor nutritional habits. Government should encourage people to farm and provide necessary incentives to ensure adequate food security in the country. Storage and processing facilities be provided to ensure the availability and affordability of food items like fruits and green vegetables across the seasons. The dietary habits of carbohydrates all days by the rural people and dependence on refined and imported food products by the urban subjects are discouraged.

\section{REFERENCES}

[1] National Research Council. Diet and Health: Implications for Reducing Chronic Disease Risk. National Academy Press, Washington DC, 1989.

[2] World Health Organization. Diet, Nutrition and the Prevention of Chronic Diseases. Report of a WHO Study Group, WHO Technical Report Series No. 797, WHO, Geneva, 1990.

[3] National Nutrition Policy, Government of India, Department of Women and Child Development, Ministry of Human Resources Development, New Delhi, 1993.

[4] Reddy V, Pralhad Rao N, Sastry JG and Kasinath K. Nutrition Trends in India. National Institute of Nutrition, Hyderabad, 1993.

[5] Raghuram TC, Pasricha S. and Sharma RD. Diet and Diabetes. National Institute of Nutrition, Hyderabad, 1993.

[6] Gopalan C. Nutrition Research in South-East Asia: The Emerging Agenda of the Future. WHO Regional Office for South-East Asia, New Delhi, 1994.

[7] Indian Council of Medical Research. Nutrient Requirements and Recommended Dietary Allowances for Indians, National Institute of Nutrition, Hyderabad, 2010.

[8] Ghafoorunissa and Kamala Krishnaswamy. Diet and Heart Disease. National Institute of Nutrition, Hyderabad, 1995.

[9] Gopalan C, Rama Sastri BV. and Balasubramanian SC. Nutritive Value of Indian Foods. Revised and updated by Narasinga Rao BS, Deosthale YG and Pant KC., National Institute of Nutrition, Hyderabad, 1996. 